\title{
A novel biomarker of chronic allograft dysfunction in renal transplant recipients (serum calreticulin and CD47)
}

\author{
Rasha Ibrahim Abdel Razek Gawish ${ }^{1 *}$, Hayam Abdel Meguid El Aggan', Sabah Abdel Hady Mahmoud² and
} Sara Ahmed Mohamed Mortada ${ }^{3}$

\begin{abstract}
Background: Chronic allograft dysfunction (CAD) is considered the leading cause of late allograft loss. The cluster of differentiation 47 (CD47) and calreticulin (CRT) are involved in many and diverse cellular processes. The present study was designed to study the role of the pro-phagocytic CRT and anti-phagocytic CD47 signals in patients with renal transplantation in relation to graft function.

Thirty renal transplantation recipients (RTR) for more than 6 months [15 with stable renal function and 15 with chronic allograft dysfunction (CAD)] and 15 healthy controls were enrolled in the study. Quantification of CRT, CD47, and high-sensitivity C-reactive protein (hsCRP) levels in serum was done using standardized enzyme-linked immunosorbent assay (ELISA) kits. Measurement of renal function and urinary alkaline phosphatase (U.ALP) was done. Renal interstitial fibrosis (IF) was graded in renal biopsies of CAD.
\end{abstract}

Results: Serum CRT and urinary ALP levels were statistically significant higher $(P<0.001)$ while serum CD47 level was statistically significant lower $(P<0.001)$ in patients with CAD than patients with stable graft function and controls. There was statistically insignificant difference between controls and patients with stable graft function. Serum CRT and serum CD47 levels were positively correlated with each other and with worsening renal and tubular function, serum hsCRP in RTR and with degree of renal IF in patients with CAD $(P<0.05)$.

Conclusions: The activation and dysregulation of CRT and CD47 could play a role in the development of CAD and could be a potential biomarker for renal allograft dysfunction.

Keywords: Chronic allograft dysfunction, Pro-phagocytic calreticulin (CRT), Anti-phagocytic CD47

\section{Background}

Renal transplantation is accepted as the most effective form of renal replacement therapy that improves patient survival, reduces morbidity, is cost-effective, improves quality of life, releases from the tedium of dialysis, and facilitates social rehabilitation of patients with end stage renal disease (ESRD). Therefore, renal transplantation is the treatment of choice for most ESRD patients. Although

\footnotetext{
* Correspondence: gawishrasha@gmail.com

${ }^{1}$ Nephrology Unit, Faculty of Medicine, Alexandria University, Alexandria, Egypt

Full list of author information is available at the end of the article
}

the most important problems in renal transplantation are organ availability and late graft loss $[1,2]$.

With the recognition of alloantibodies as the major factor that leads to graft dysfunction, the term "chronic allograft nephropathy" has been replaced by more specific terminology in the Banff classification of renal allograft pathology. A frequent pathologic feature of chronic allograft injury is interstitial fibrosis or tubular atrophy $[3,4]$.

Chronic interstitial fibrosis and tubular atrophy may also result from damage to the allograft during the phase of ischemia-reperfusion injury (IR) or early acute rejection, calcineurin inhibitor (CNI) nephrotoxicity, recurrent glomerular disease, and BK virus (BKV) infection [4]. 
Calreticulin (CRT) is an evolutionarily conserved protein that is a major calcium $2+(\mathrm{Ca} 2+-)$ binding (storage) protein in the lumen of the endoplasmic reticulum (ER) $[5,6]$. The CRT is a $46 \mathrm{kDa}$ (400 amino acid residues) in the lumen of endoplasmic reticulum (ER) as a major $\mathrm{Ca} 2+$ binding chaperon [7]. Biochemical and structural studies have demonstrated three distinct structural domains of CRT: the amino-terminal $\mathrm{N}$-domain, the middle P-domain, and the carboxyl-terminal C-domain. The protein also contains a cleavable amino acid signal sequence at the beginning of $\mathrm{N}$-terminal directing the protein to ER and an ER retention/retrieval signal at the C-terminal [6, 8]. It also plays two main functions in ER as a chaperon and as a $\mathrm{Ca} 2+$ binding and storage protein. CRT is also found in several other sub-cellular locations: the cell surface, cytoplasm, and extracellular marix (ECM) [8].

The ER stress and apoptosis are recognized as major contributors to progression of renal fibrosis $[9,10]$. A central mediator in fibrosis is the profibrotic cytokine transforming growth factor $\beta$ (TGF- $\beta 1$ ), the expression of which was decreased in CRT heterozygous mice [11].

The CRT serves as a pro-phagocytic signal by binding to its macrophage receptor, low-density lipoproteinrelated protein (LRP-1), which leads to engulfment of the target cell [12]. The translocation of CRT to plasma membrane constitutes one of the crucial features of immunogenic tumor cell death, presumably because surface-exposed CRT facilitates the engulfment of dying tumor cells by phagocytes [13]. Upregulation of CRT during fibrosis may be involved in establishment of the inflammatory state that characterizes the fibrotic kidney, thereby increasing TGF- $\beta 1$ production [14]. CRT expressed on the cell surface is considered as an "eat-me" signal for multiple human cancers [15].

The CD47 is also known as integrin-associated protein (IAP). It is a cell surface protein of the immunoglobulin (Ig) superfamily, which is heavily glycosylated and expressed by virtually all cells in the body. The CD47 was first recognized as a $50 \mathrm{kDa}$ protein associated and copurified with the $\alpha \mathrm{v} \beta 3$ integrin in placenta and neutrophil granulocytes and later shown to have the capacity to regulate integrin function and the responsiveness of leukocytes to tripeptide arginine-glycine-aspartic acid (RGD)-containing extracellular matrix proteins [16, 17].

The CD47 functions as an inhibitor of phagocytosis through ligation to transmembrane signal-regulatory proteins alpha $(\operatorname{SIRP} \alpha)$, SIRP $\gamma$, and also the ligands thrombospondin-1 (TSP-1) particularly expressed on the myeloid-lineage hematopoietic cells including macrophages. The TSP1 and CD47 are upregulated in ischemia reperfusion injury (IRI) and that the absence or disruption of TSP1-CD47 signaling provides protection from soft tissue, liver, and renal IRI. So activation of CD47, TSP1 limits renal tubular cells (rTEC) proliferation and self- renewal after IRI [18], although the role of this interaction in renal recovery is unknown [19]. CD47 serves as a "don't eat me" signal and might be a central actor in the tumor microenvironment to escape innate immune surveillance through evasion of phagocytosis [20,21].

Therefore, the aim of the present work was to study the role of the pro-phagocytic calreticulin and the antiphagocytic CD47 signals in renal transplant recipients and their relation to chronic allograft function.

\section{Methods \\ Study population}

The present study included 30 recipients of RT for more than 6 months [15 RTR with stable renal function (serum creatinine $\leq 2 \mathrm{mg} / \mathrm{dl}$ ) (group I) and $15 \mathrm{RTR}$ with CAD (serum creatinine $>2 \mathrm{mg} / \mathrm{dl}$ )], (group II), who were referred to the Nephrology and Transplantation Unit, Department of Internal Medicine. Also, 15 healthy subjects of matched age and sex were included as controls (group III) (Table 1).

The patients were selected after exclusion of viral infections, underlying chronic liver disease, pre-transplant diabetes mellitus or hyperlipidemia, connective tissue and autoimmune diseases, other infections or inflammatory disorders, any kind of malignancy, cardiac and respiratory diseases, and previous drug intake other than the immunosuppressive drugs.

The study was conducted in accordance with the provisions of the Declaration of Helsinki and Good Clinical Practice guidelines. An informed consent was obtained from all subjects included in the study. It was approved by the Research Ethics Committee/the Institutional Review Board of the Faculty of Medicine.

All RTR were evaluated clinically as regards original renal disorders, previous RT, number of attacks of acute rejection, other post-transplantation complications, viral infections [hepatitis $\mathrm{C}$ virus, hepatitis $\mathrm{B}$ virus, human immunodeficiency virus, and cytomegalovirus] and immunosuppressive regimens [corticosteroids, cyclosporine and mycophenolate mofetil]. Therapeutic immunosuppressive drug was monitored for all transplanted patients [22].

\section{Laboratory investigations}

Laboratory investigations included complete blood picture [23], complete urine analysis, renal function tests [blood urea, serum creatinine [24], estimated glomerular filtration rate (eGFR) using the Chronic Kidney Disease Epidemiology Collaboration formula [25] and urinary albumin/creatinine ratio (ACR)] [23]. Serum levels of high-sensitivity C-reactive protein (hsCRP), a marker of systemic inflammation, were measured using enzyme-linked immunosorbant assay (ELISA) kit (Cusabio, Wuhan, Hubei Province, China) [26] Urinary alkaline phosphatase (U.ALP) was measured 
Table 1 Characteristics of renal transplant recipients with stable renal function and chronic allograft dysfunction (CAD) and healthy controls

\begin{tabular}{|c|c|c|c|c|}
\hline \multirow[t]{2}{*}{ Variables } & \multicolumn{2}{|c|}{ Renal transplant recipients } & \multirow{2}{*}{$\begin{array}{l}\text { Healthy controls } \\
(n=15)\end{array}$} & \multirow[t]{2}{*}{$P$ value $^{*}$} \\
\hline & $\begin{array}{l}\text { Stable renal function } \\
(n=15)\end{array}$ & $\begin{array}{l}\text { CAD } \\
(n=15)\end{array}$ & & \\
\hline Age (years) & $42.27 \pm 7.32$ & $39.40 \pm 10.57$ & $36.53 \pm 5.25$ & 0.160 \\
\hline \multicolumn{5}{|l|}{ Gender } \\
\hline Male, $n(\%)$ & $9(60 \%)$ & $11(73.3 \%)$ & $8(53.3 \%)$ & \multirow[t]{2}{*}{$0.516^{\mathrm{a}}$} \\
\hline Female, $n(\%)$ & $6(40 \%)$ & $4(26.7 \%)$ & $7(46.7 \%)$ & \\
\hline Renal transplantation duration (years) & $4.47 \pm 2.91$ & $3.57 \pm 2.39$ & - & $0.427^{b}$ \\
\hline Creatinine (mg/dl) & $1.23 \pm 0.34^{\dagger}$ & $2.69 \pm 0.47^{\dagger \ddagger}$ & $0.91 \pm 0.12$ & $<0.001$ \\
\hline $\mathrm{eGFR}\left(\mathrm{ml} / \mathrm{min} / 1.73 \mathrm{~m}^{2}\right)$ & $65.09 \pm 19.02^{\dagger}$ & $27.44 \pm 6.96^{\dagger \ddagger}$ & $103.4 \pm 13.19$ & $<0.001$ \\
\hline Urinary ACR (mg/g) & $268.2 \pm 137.5^{\dagger}$ & $332.7 \pm 319.1^{\dagger}$ & $21.53 \pm 5.64$ & $<0.001$ \\
\hline hsCRP (mg/l) & $6.07 \pm 3.45^{\dagger}$ & $13.33 \pm 7.89^{\dagger}$ & $2.33 \pm 0.65$ & $<0.001$ \\
\hline Urinary alkaline phosphatase (U/I) & $37.65 \pm 16.55$ & $57.26 \pm 21.57^{\dagger \neq}$ & $42.58 \pm 11.43$ & 0.008 \\
\hline Calreticulin (ng/ml) & $2.60 \pm 0.51$ & $3.77 \pm 1.03^{\dagger \neq}$ & $2.12 \pm 0.39$ & $<0.001$ \\
\hline CD47 (pg/ml) & $1642.83 \pm 894.99$ & $907.30 \pm 343.99^{\dagger \ddagger}$ & $2092.87 \pm 1015.32$ & $<0.001$ \\
\hline \multicolumn{5}{|l|}{ Renal interstitial fibrosis } \\
\hline Mild, $n(\%)$ & - & $6(40 \%)$ & - & \\
\hline Moderate, $n(\%)$ & - & $5(33.33 \%)$ & - & \\
\hline Severe, $n(\%)$ & - & $4(26.66 \%)$ & - & \\
\hline \multicolumn{5}{|c|}{$\begin{array}{l}\text { eGFR estimated glomerular filtration rate, } A C R \text { albumin/creatinine ratio, } h S C R P \text { high-sensitivity C-reactive protein. Continuous data are represented as mean } \pm S D \\
\text { and categorical data are represented as number and percentages }\end{array}$} \\
\hline
\end{tabular}

as a marker for tubular function by the spectrophotometric method [27, 28].

Quantification of calreticulin (CRT) and CD47 levels in serum was performed using a standardized commercially available enzyme-linked immunosorbent assay (ELISA) kits [29].

\section{Radiological examination}

Abdominal ultrasonograghy was done to assess the kidney allograft size, shape, echogenicity, corticomedullary differentiation, presence of stones, masses, hydronephrosis, or lymphocele [30].

\section{Histopathological examination}

Renal allograft biopsies obtained from RTR with CAD were fixed in $10 \%$ formalin solution, embedded in paraffin, sectioned (5 $\mu \mathrm{m}$ thick), and subsequently stained with hematoxylin-eosin, and trichrome stains were used to quantify histologic findings of CAD and the degree of renal interstitial fibrosis (IF) according to the Banff interstitial fibrosis $(c i)$ score as follows: (1) ci0: interstitial fibrosis in up to $5 \%$ of cortical area, (2) ci1: interstitial fibrosis in 6 to $25 \%$ of cortical area (mild interstitial fibrosis), (3) ci2: interstitial fibrosis in 26 to $50 \%$ of cortical area (moderate interstitial fibrosis), (4) ci3: interstitial fibrosis in $>50 \%$ of cortical area (severe interstitial fibrosis) [31, 32].

\section{Statistical analysis}

Data were fed to the computer and analyzed using IBM SPSS software package version 20.0. (Armonk, NY: IBM Corp.) Qualitative data were described using number and percent. Fisher's exact test with Monte Carlo corrected significance was used for comparison between groups. The Kolmogorov-Smirnov test was used to verify the normality of distribution. Quantitative data were described using range (minimum and maximum), mean and standard deviation. For normally distributed continuous data, comparison between groups was done using the Student's $t$ test and one-way ANOVA test with post hoc test (Tukey) for pairwise comparisons. KruskalWallis test was used for non-normally distributed data and when the test was positive, Dunn's for multiple comparisons test was done for pairwise comparisons in a post hoc fashion. Correlations between variables were analyzed using Spearman's rank test.

Receiver operating characteristic (ROC) curve was used to determine the sensitivity, specificity, cut-off value, and 
area under the curve (AUC) with a 95\% confidence interval of serum calreticulin, CD47, and serum hsCRP in discriminating RTR with CAD from those with stable renal function. Significance of the obtained results was judged at the $5 \%$ level.

\section{Results}

\section{Clinical results}

Duration of transplantation in group I ranged from 0.5 to 10 years with a mean of $4.47 \pm 2.91$ years. In group II, it ranged from 1 to 10 years with a mean of $3.57 \pm 2.39$ years. There was insignificant difference between the two groups of patients $(U=93.500, P=0.427)$ (Table 1$)$.

In the present study, four patients of group I suffered from acute rejection episode at one month post transplantation and five patients of group II at 1, 3, 4, 5, and 6 months post transplantation. Cyclosporine toxicity was diagnosed in 2 patients of group I and in 3 patients of group II. One patient of group I and two patients of group II had a history of acute tubular necrosis (ATN) which occurred just after transplantation and led to delayed graft function (DGF) (Table 1).

\section{Laboratory results}

Serum creatinine levels was significantly higher in RTR with CAD and those with stable renal function than the healthy controls and in patients with CAD than patients with stable renal function $(P<0.001)$. Urinary ACR and serum hsCRP levels were significantly higher in both groups with RTR than healthy controls with insignificant difference between patients with CAD and those with stable renal function $(P<0.001$ for both). By contrast, eGFR showed significant decreases in RTR with stable renal function and CAD compared with healthy controls and in RTR with CAD compared with those with stable renal function $(P<0.001)$. Urinary ALP was significantly higher in RTR with CAD than those with stable renal function and the healthy controls with insignificant difference between patients with stable renal function and the healthy controls $(P=0.008)$ (Table 1$)$.

By plotting ROC curve, the sensitivity and specificity of the hsCRP level in discriminating RTR with stable allograft function from RTR with CAD were $73.3 \%$ and $60 \%$, respectively, at a cut-off level of $6 \mathrm{mg} / \mathrm{l}$ (area under the curve $=0.798)$ (Fig. 1).

\section{Serum calreticulin}

Serum calreticulin levels ranged between 1.50 and 3.50 $\mathrm{ng} / \mathrm{ml}$ with a mean of $2.60 \pm 0.51 \mathrm{ng} / \mathrm{ml}$ in RTR with stable function, in RTR with CAD it ranged from 2.30 to $5.50 \mathrm{ng} / \mathrm{ml}$ with a mean of $3.77 \pm 1.03 \mathrm{ng} / \mathrm{ml}$ and in healthy controls it ranged from 1.4 .00 to $2.50 \mathrm{ng} / \mathrm{ml}$ with a mean of $2.12 \pm 0.39 \mathrm{ng} / \mathrm{ml}$. There was statistically significant difference between the three groups $(H=$ 25.403, $P<0.001)$. It was significantly higher in RTR with CAD than RTR with stable renal function and healthy controls. There was insignificant difference between RTR with stable renal function and healthy controls (Table 1, Fig. 2).

Serum calreticulin in RTR with stable function and CAD was positively correlated with serum creatinine $(r$ $=0.753, P=0.001, r=0.673, P=0.006$, respectively),

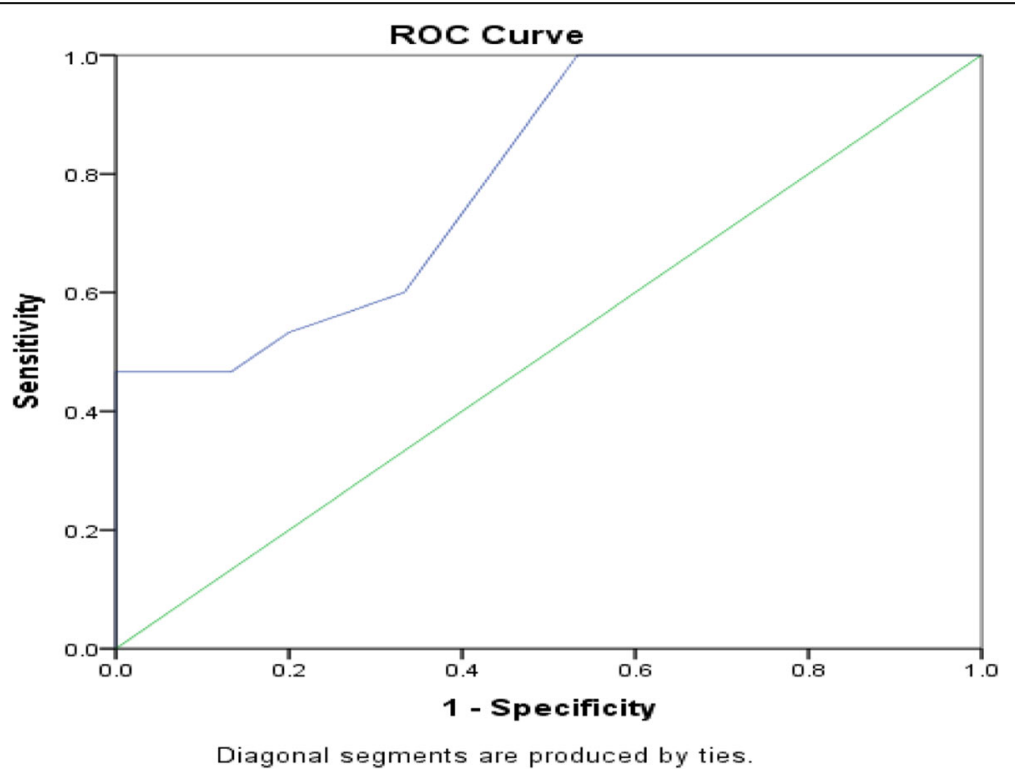

Fig. 1 Receiver operating characteristic curve (ROC) shows that the sensitivity and specificity of the high-sensitivity C-reactive protein (hsCRP) level in discriminating renal transplant recipients with stable allograft function from renal transplant recipients with chronic allograft dysfunction were $73.3 \%$ and $60 \%$, respectively, at a cut-off level of $6 \mathrm{mg} / \mathrm{l}$ (area under the curve $=0.798$ ) 


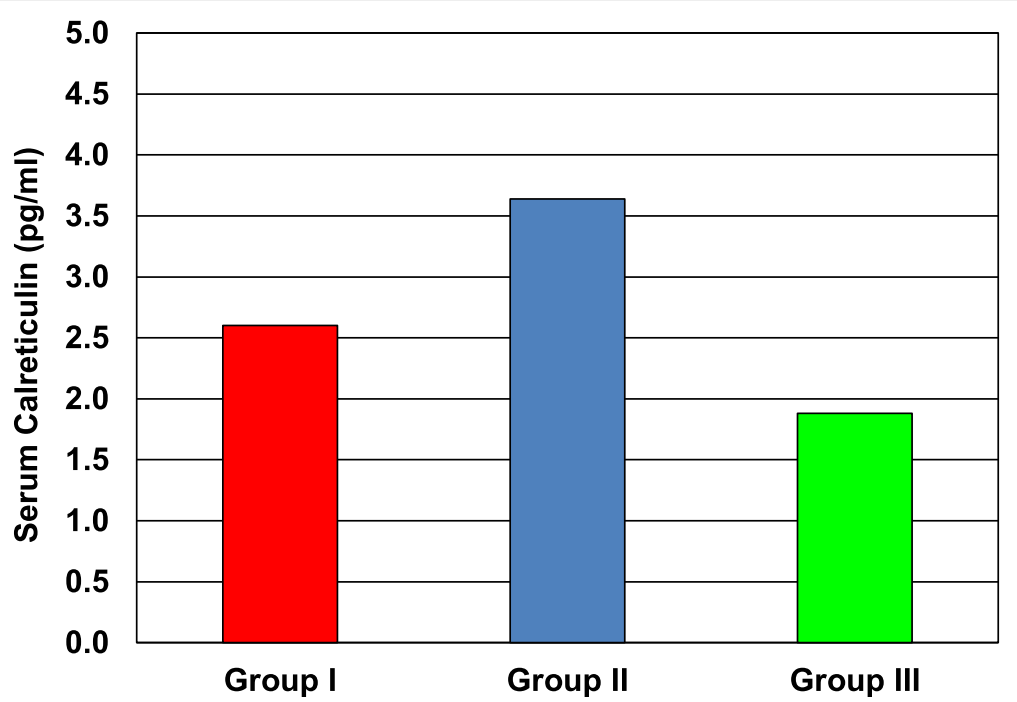

Fig. 2 Serum calreticulin (CRT) (ng/ml) in renal transplant recipients with stable allograft function (group I), chronic allograft dysfunction (group II), and in control subjects (group III)

hsCRP $(r=0.694, P=0.004, r=0.720, P=0.002$, respectively), urinary alkaline phosphatase $(r=0.592, P=$ $0.020, r=0.597, P=0.019$, respectively), and serum CD47 ( $r=0.577, P=0.024)$, $(r=0.994, P<0.001$, respectively) and with U.ACR in RTR with stable renal function $(r=0.549, P=0.034)$. It was inversely correlated e-GFR $(r=-0.721, P=0.002)$ in RTR with stable renal function. In RTR with CAD, serum celreticulin was positively correlated with the degree of renal IF ( $r=$ $0.712, P=0.003$ ) (Table 2, Fig. 3).

By plotting ROC curve, the sensitivity and specificity of the serum CRT level in discriminating RTR with stable allograft function from RTR with CAD were $86.7 \%$ and $73.3 \%$, respectively, at a cut-off level of 2.6 $\mathrm{ng} / \mathrm{ml}$ (area under the curve $=0.842$ ) (Fig. 4).

\section{Serum CD47}

Serum CD47 levels ranged between 648 and $4410.0 \mathrm{pg} /$ $\mathrm{ml}$ with a mean of $1642.83 \pm 894.99 \mathrm{pg} / \mathrm{ml}$ in RTR with stable function, in RTR with CAD ranged from 404.0 to $1517.0 \mathrm{pg} / \mathrm{ml}$ with a mean of $907.30 \pm 343.99 \mathrm{pg} / \mathrm{ml}$ and in healthy subjects it ranged from $1085.0-4040.0 \mathrm{pg} / \mathrm{ml}$ with a mean of $2092.87 \pm 1015.32 \mathrm{pg} / \mathrm{ml}$. There was significant difference between the three groups $(H=$ 17.815, $P<0.001)$. It was significantly higher in RTR with CAD than RTR with stable renal function and healthy controls. There was insignificant difference between RTR with stable renal function and healthy controls (Table 1, Fig. 5).

Serum CD47 in RTR with stable function and CAD was positively correlated with serum creatinine $(r=0.713, P=$

Table 2 Statistical correlations between serum calreticulin (CRT) levels ( $\mathrm{ng} / \mathrm{ml}$ ) on the one hand and serum CD47, renal function, high-sensitivity C-reactive protein (hsCRP), urinary alkaline phosphatase, and degree of renal fibrosis on the other hand in renal transplant recipients (RTR) with stable renal function and chronic allograft dysfunction (CAD)

\begin{tabular}{|c|c|c|c|c|}
\hline \multirow[t]{3}{*}{ Variables } & \multicolumn{4}{|c|}{ Serum calreticulin $(\mathrm{ng} / \mathrm{ml})$} \\
\hline & \multicolumn{2}{|c|}{$\begin{array}{l}\text { RTR with stable renal function } \\
(n=15)\end{array}$} & \multicolumn{2}{|c|}{$\begin{array}{l}\text { RTR with CAD } \\
(n=15)\end{array}$} \\
\hline & $r$ & $P$ & $r$ & $P$ \\
\hline Serum CD47 (pg/ml) & 0.577 & 0.024 & 0.994 & $<0.001$ \\
\hline Serum creatinine (mg/dl) & 0.753 & 0.001 & 0.673 & 0.006 \\
\hline $\operatorname{eGFR}\left(\mathrm{ml} / \mathrm{min} / 1.73 \mathrm{~m}^{2}\right)$ & -0.721 & 0.002 & -0.454 & 0.089 \\
\hline Urinary ACR (mg/g) & 0.549 & 0.034 & 0.319 & 0.247 \\
\hline hsCRP (mg/l) & 0.694 & 0.004 & 0.720 & 0.002 \\
\hline $\begin{array}{l}\text { Urinary alkaline phosphatase } \\
(\mathrm{U} / \mathrm{I})\end{array}$ & 0.592 & 0.020 & 0.597 & 0.019 \\
\hline Renal interstitial fibrosis & - & - & 0.712 & 0.003 \\
\hline
\end{tabular}

eGFR estimated glomerular filtration rate, $A C R$ albumin/creatinine ratio, $h s C R P$ high-sensitivity C-reactive protein, $r$ Spearman correlation coefficient 


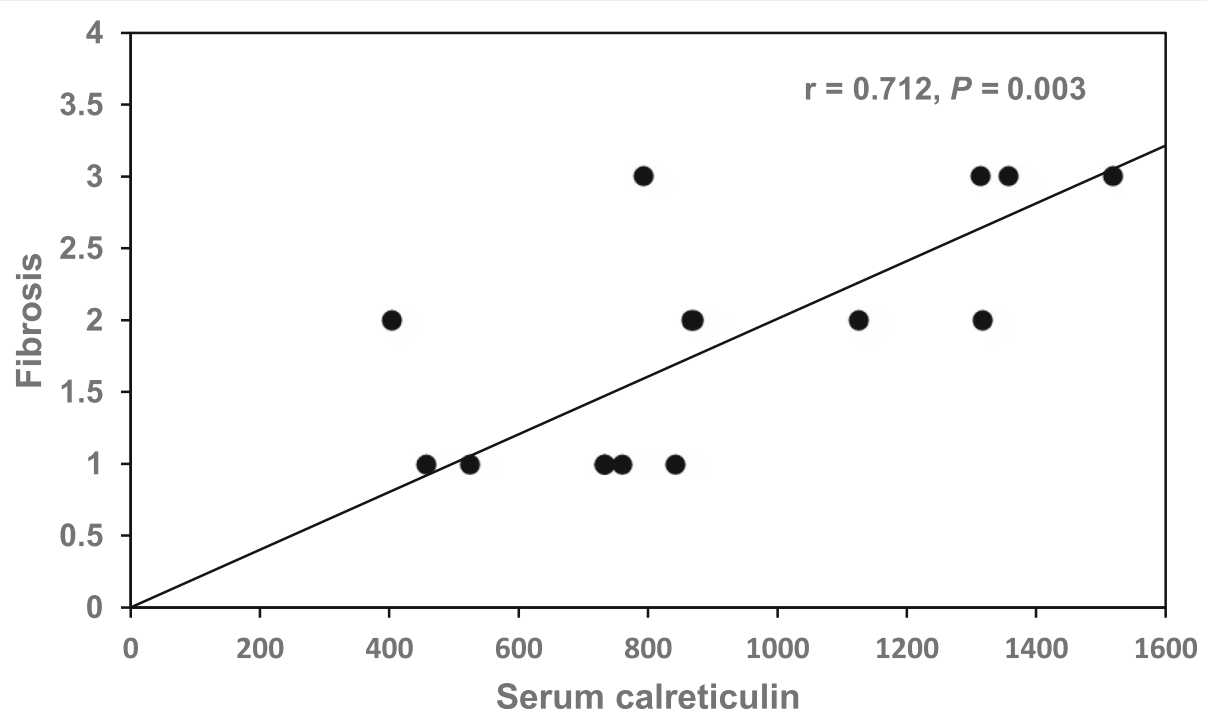

Fig. 3 Correlation between serum calreticulin (S. CRT) level (ng/dl) with the degree of renal fibrosis in renal transplant recipients with chronic allograft dysfunction

0.003, $r=0.629, P=0.012$, respectively), hsCRP $(r=0.797$, $P=<0.001, r=0.680, P=0.005$, respectively), urinary alkaline phosphatase $(r=0.529, P=0.043, r=0.581, P=$ 0.023 , respectively), and with U.ACR in RTR with stable renal function $(r=0.671, P=0.006$. It was inversely correlated e-GFR $(r=-0.543, P=0.037)$ in RTR with stable renal function. In RTR with CAD, serum CD47 was positively correlated with the degree of renal IF $(r=0.692$, $P=0.004$ ) (Table 3, Fig. 6).

By plotting ROC curve, the sensitivity and specificity of the serum CD47 level in discriminating RTR with stable allograft function from RTR with CAD were $73.3 \%$ and $73.3 \%$, respectively, at a cut-off level of 1186 $\mathrm{pg} / \mathrm{ml}$ (area under the curve $=0.824$ ) (Fig. 7).

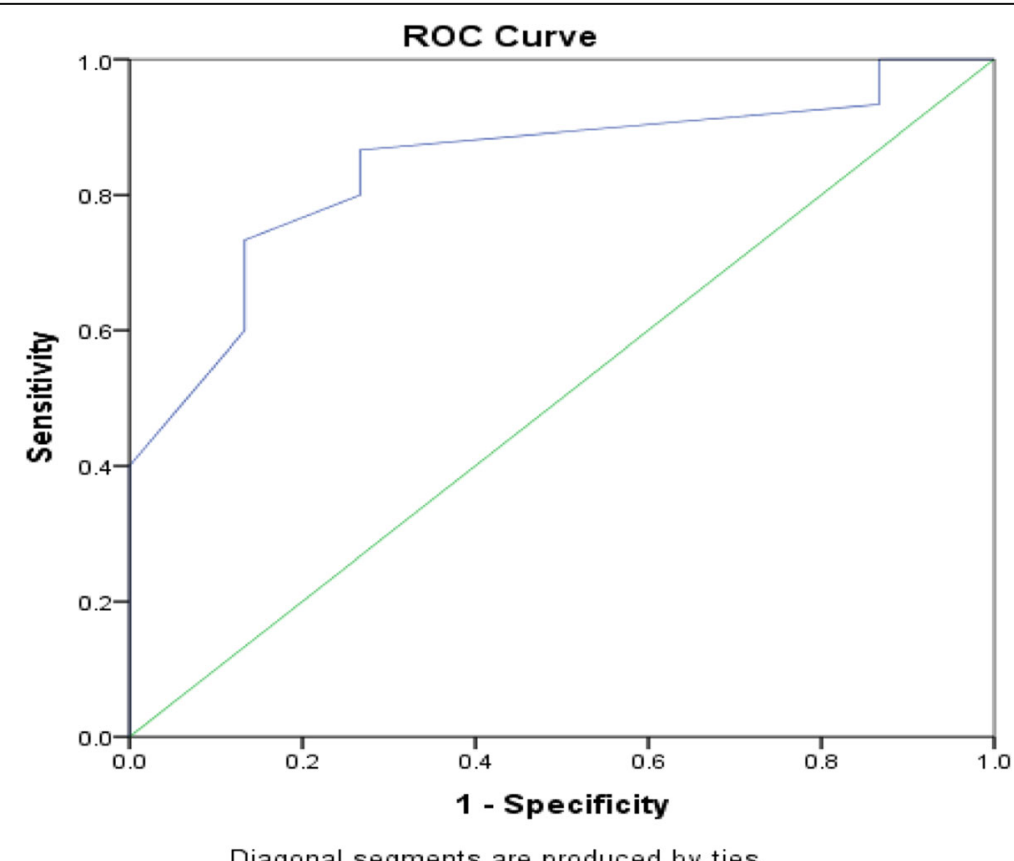

Fig. 4 Receiver operating characteristic curve (ROC) shows that the sensitivity and specificity of the calreticulin (CRT) level in discriminating renal transplant recipients with stable allograft function from renal transplant recipients with chronic allograft dysfunction were $86.7 \%$ and $73.3 \%$, respectively, at a cut-off level of $2.6 \mathrm{ng} / \mathrm{ml}$ (area under the curve $=0.842$ ) 


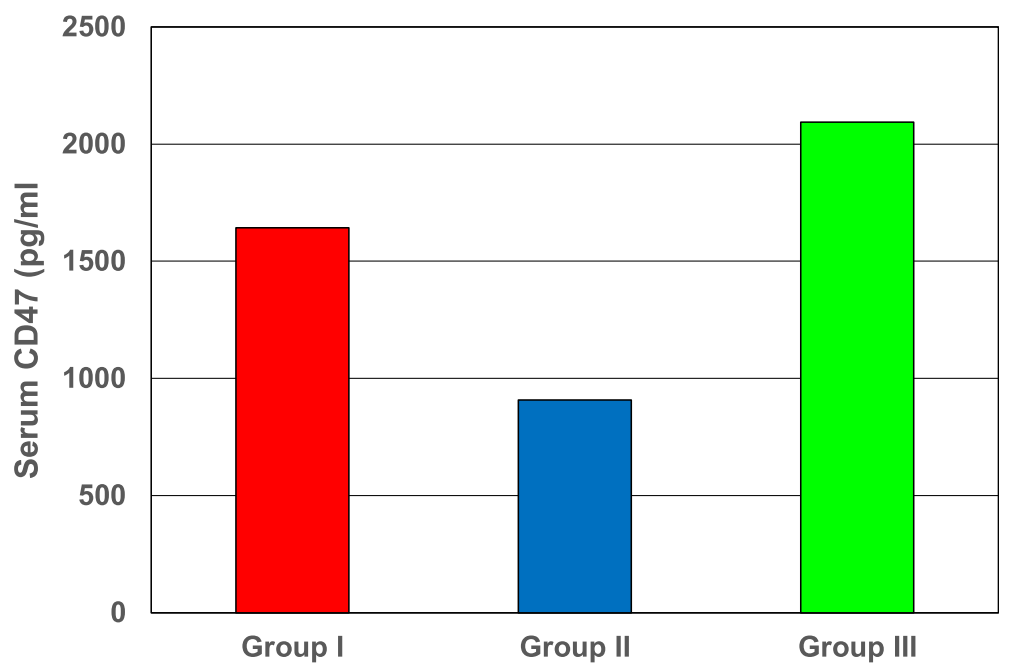

Fig. 5 Serum CD47 (pg/ml) in renal transplant recipients with stable allograft function (group I), chronic allograft dysfunction (group II), and in control subjects (group III)

\section{Radiological examination Ultrasound}

In patients with stable renal function conventional ultrasound examination was normal except in five patients, it showed mild increase in echogenicity. In all patients with chronic allograft dysfunction, the kidneys showed increased cortical echogenicity, reduced size, and fair corticomedullary differentiation. A well-defined an-echoic cystic collection situated between the graft and urinary bladder (lymphocele) was detected in one patient of group I and 2 patients of group II.

\section{Histopathological evaluation}

All renal biopsies which had been taken showed picture of chronic allograft nephropathy. Glomerular changes with double contour of the peripheral capillary loops moderate and increase in the mesangial matrix (five biopsies with cg2, six cg1 and four cg0, eleven $\mathrm{mm} 1$, and four $\mathrm{mm} 0$ ) vascular changes with fibrous intimal thickening and narrowing of the included arteries (thirteen cv1 and two cv2). Mild arteriolar hyaline thickening was detected in 13 of them (ah1). Ten biopsies showed few foci of mild tubulitis ( $\mathrm{t} 1$ ). The degree of renal IF in RTR with CAD was mild (ci1) in 6 patients $(40 \%)$, moderate (ci2) in 5 patients $(33.33 \%)$, and severe (ci3) in 4 patients (26.66\%) (Table 1).

\section{Discussion}

Upregulation of CRT during fibrosis may be involved in establishment of the inflammatory state that characterizes the fibrotic kidney, with increasing TGF- $\beta 1$ production [14].

The present work showed a significant increase in serum levels of CRT in RTR and was more pronounced in patients with CAD with insignificant difference between RTR with stable renal function and controls

Table 3 Statistical correlations between serum serum CD47 levels (pg/ml) on the one hand and renal function, high-sensitivity Creactive protein (hsCRP), urinary alkaline phosphatase, and degree of renal fibrosis on the other hand in renal transplant recipients (RTR) with stable renal function and chronic allograft dysfunction (CAD)

\begin{tabular}{|c|c|c|c|c|}
\hline \multirow[t]{3}{*}{ Variables } & \multicolumn{4}{|c|}{ Serum CD47 (pg/ml) } \\
\hline & \multicolumn{2}{|c|}{$\begin{array}{l}\text { RTR with stable renal function } \\
(n=15)\end{array}$} & \multicolumn{2}{|c|}{$\begin{array}{l}\text { RTR with CAD } \\
(n=15)\end{array}$} \\
\hline & $r$ & $P$ & $r$ & $P$ \\
\hline Serum creatinine (mg/dl) & 0.713 & 0.003 & 0.629 & 0.012 \\
\hline $\mathrm{eGFR}\left(\mathrm{ml} / \mathrm{min} / 1.73 \mathrm{~m}^{2}\right)$ & -0.543 & 0.037 & -0.461 & 0.084 \\
\hline Urinary ACR (mg/g) & 0.671 & 0.006 & 0.266 & 0.338 \\
\hline hsCRP (mg/l) & 0.797 & $<0.001$ & 0.680 & 0.005 \\
\hline Urinary alkaline phosphatase (U/I) & 0.529 & 0.043 & 0.581 & 0.023 \\
\hline Renal interstitial fibrosis & - & - & 0.692 & 0.004 \\
\hline
\end{tabular}

eGFR estimated glomerular filtration rate, $\boldsymbol{A C R}$ albumin/creatinine ratio, $\boldsymbol{h S C R P}$ high-sensitivity C-reactive protein, $r$ Spearman correlation coefficient 


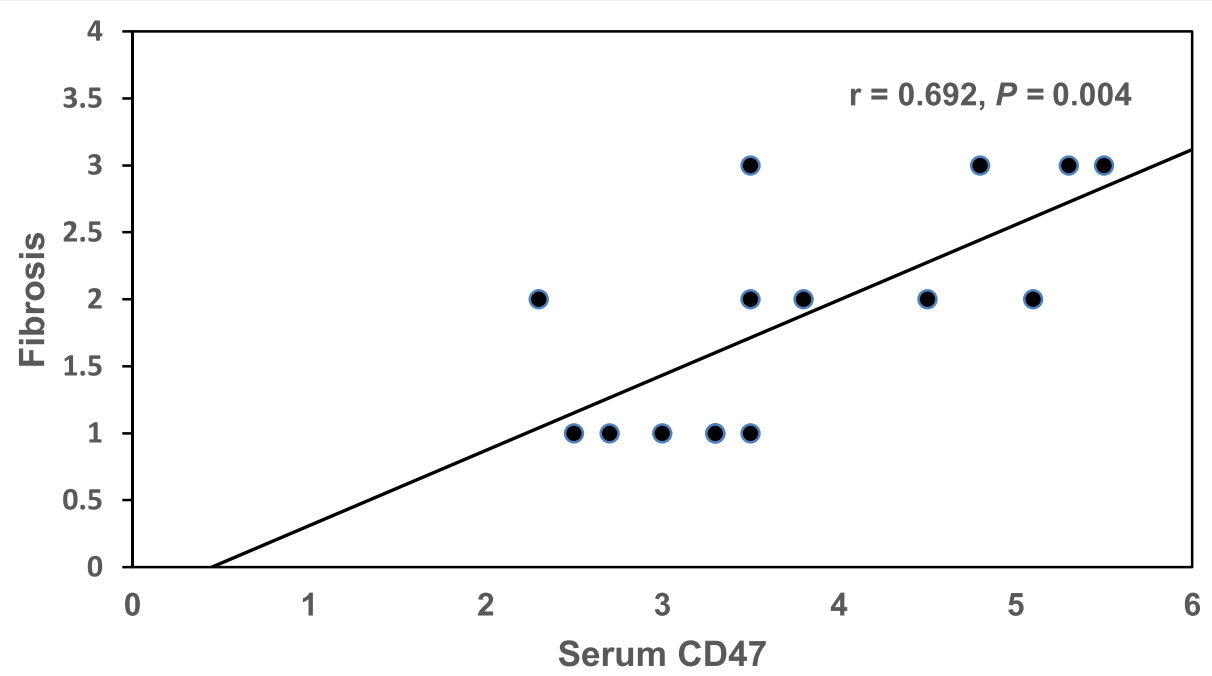

Fig. 6 Correlation between serum CD47 (S. CD47) (pg/ml) with the degree of renal fibrosis in renal transplant recipients with chronic allograft dysfunction

group and was positively correlated with worsening of renal function, tubular dysfunction and the degree of renal fibrosis. This denotes that there is activation and upregulation of CRT in renal transplant recipients with deterioration of renal function. The present study showed high sensitivity and specificity of serum CRT in discriminating RTR with stable renal function from RTR with CAD. So, it could be a good marker of allograft function and provide a biochemical basis for the development of block of S.CRT and targeting therapy for treatment and even prevention of renal deterioration. To our knowledge, this is the first study addressing the association between serum CRT levels and human renal allograft dysfunction.

Previous studies demonstrated increased CRT levels in patients with CKD and renal fibrosis [33, 34], diabetes with worsening renal function [35], systemic lupus erythematosus with organ damage [36] rheumatoid arthritis [37] essential thrombocytopenia [38], immune response [39], and human cancer [40].

It was found that CRT facilitates the folding of major histocompatibility complex (MHC) class I molecules,

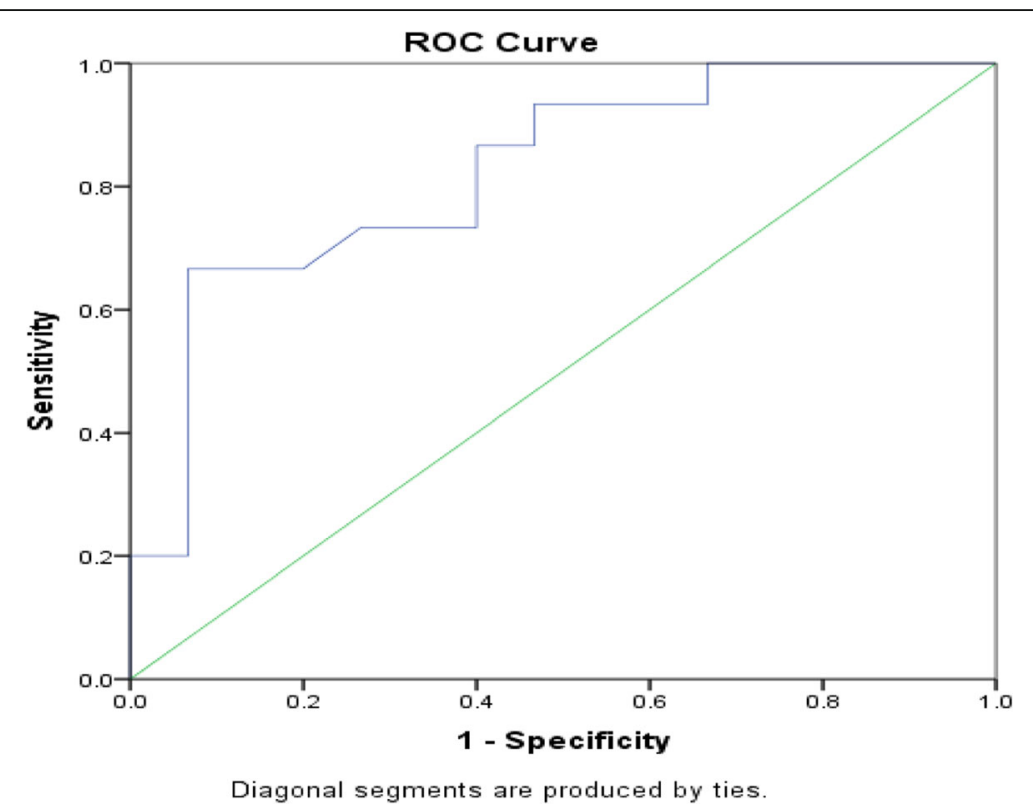

Fig. 7 Receiver operating characteristic curve (ROC) shows that the sensitivity and specificity of the CD47 level in discriminating renal transplant recipients with stable allograft function from renal transplant recipients with chronic allograft dysfunction were $73.3 \%$ and $73.3 \%$, respectively, at a cut-off level of $1186 \mathrm{pg} / \mathrm{ml}$ (area under the curve $=0.824$ ) 
thereby influencing antigen presentation to cytotoxic $\mathrm{T}$ cells [39]. The macrophages with a higher surface CRT showed a stronger phagocytic ability to cancer cell phagocytosis, blockade of CRT on macrophages diminished phagocytosis [40]. Adiponectin binding to CRT on the macrophage cell surface can protect from systemic inflammation by promoting apoptotic cell clearance and reduced features of autoimmunity in lpr mice [35]. Wang et al. [36] reported elevated levels of CRT among patients with systemic lupus erythematosus (SLE) and with the presence of cumulative organ damage. The CRT level was correlated with the presence of lupus nephritis and disease activity index. Also, in juvenile idiopathic arthritis (JIA), the elevation of CRT was correlated with disease activity and severity parameters [37].

Regarding this study, serum CD47 level was significantly lower in RTR with CAD than RTR with stable renal function and controls group, and there was a positive correlation between the S.CD47 and S.CRT, and both with markers of renal function, tubular injury, and the degree of renal fibrosis. This means that with the increase of S.CRT, the S.CD47 increase to balance the excessive function of CRT with increase apoptosis [41]. So, in this study, there is a downregulation in the S.CD47 in RTR with CAD with incomplete compensatory mechanism in these patients. These denote that changes on the apoptotic cell create an environment where "don't eat me" signals are rendered less active and "pro-phagocytic eat me" signals, including CRT are more active [41]. Also, S.CRT and S.CD47 were positively correlated with the degree of hsCRP levels. This shows that there is an ongoing inflammation with the upregulation of CRT and downregulation of CD47 in patients with $\mathrm{CAD}$ who developed renal dysfunction. The present study showed that serum CD47 like hsCRP in discriminating RTR with stable renal function from RTR with CAD, but hsCRP is less specific than both S.CRT and S.CD47 (60\%, 73.3\%, 73.3\%, respectively). So, CD47 could share in playing a role in the pathogenesis of renal injury and a good marker of graft survival.

Many studies showed the role of CD47 in xenotransplantation rejection [42], in self-tolerance and autoimmune disease, [43] HCV infection, [44] hepatocellular carcinoma, [45] modulation of macrophage phagocytosis [46] and ischemia-reperfusion injury [19].

Navarro-Alvarez and Yang, [42], demonstrated that the CD47-SIRPa interaction has been implicated as a critical regulator of xenotransplantation rejection with the rapid rejection of CD47-deficient hematopoietic cells by macrophages in syngeneic wild-type (WT) mice. It was found that thrombospondin-1, promoted the generation of human peripheral regulatory $\mathrm{T}$ cells through the ligation of one of its receptor $\mathrm{CD} 47$ that may participate to the limitation of damage induced by exacerbated responses to self or foreign Ags in autoimmune diseases and transplantation [43] and were found to be upregulated after renal IRI in mice [19]. Latour et al. [47] showed that CD47/integrin-associated protein interacts with signalregulator protein (SIRP)- $\alpha$ and negatively regulates human $\mathrm{T}$ and dendritic cell (DC) function. In patients with chronic hepatitis, the CD47 gene was upregulated in their liver tissues and with their interaction with SIRP1 $\alpha$ on hepatic macrophages inhibits their clearance [44]. CD47 is considered as 'don't eat me' signal which acts as a myeloid immune checkpoint. Thus, the overexpression of CD47 on cancer cells is probably an outcome of immunoediting, which ensures that cancer cells escape elimination by the innate immune response of the macrophages [45].

It was found that the CRT upregulation and overexpression induced the acquisition of a pro-fibrotic phenotype in cultured tubular epithelial cells (TECs) [33]. Also, mouse embryonic fibroblasts (MEFs) that have overexpress CRT have increased collagen I RNA and protein expression [48]. Recently found that amelioration of ER stress by using the chemical chaperones such as 4-phenylbutyrate (4-PBA) [49], or Oleanolic acid and the antioxidant, $\mathrm{N}$-acetylcysteine, were recently demonstrated to ameliorate in diabetic nephropathy [50] and with CD47 blocking antibody [51] decreasing of fibrotic histological changes

Several studies have demonstrated that excreted urinary enzymes may be useful biomarkers for evaluation and diagnosis of tubular dysfunction or injury $[52,53]$.

Uurinary ALP in this work was statistically significantly higher in RTR with CAD than RTR with stable renal function and contros, and this was positively correlated with the degree of renal fibrosis. This tubular injury could be one of the pathogenesis of renal fibrosis in RTR with CAD in association with the dysregulation of both the CRT and CD47. So, the measurement of urinary enzymes as U.ALP could be a marker for assessment of the severity and progression of tubular injury and renal dysfuction in RTR.

Thus, increased excretions of tubular enzymes reflect active tubular damage and have also been reported in patients with glomerulonephritis or under nephrotoxic drug treatment [54]. The increase of ALP in urine seems to indicate a lesion of the proximal convoluted tubule and/or of an intensive regeneration of the tubular epithelial cells. And the measurement of tubular enzymes provides valuable information about early renal proximal tubular insult that ultimately may precede glomerular permeability in subjects with diabetes mellitus [55]. In RTR, Câmara et al. [56] found that unexpected high incidence (52\%) of proximal tubular dysfunction by measuring urinary retinol-binding protein ( $\mathrm{uRBP}$ ) was associated with a fivefold increased risk of chronic allograft dysfunction development and subsequent graft loss. 


\section{Conclusions}

Based on the results of the present study, it can be concluded that there is an upregulation of CRT and dysregulation of CD47 in RTR and they can share in the pathogenesis of CAD, and their measurement can discriminate renal RTR with stable allograft function from RTR with CAD. Also, the CRT and CD47 may be a novel important mediator of the fibrotic process in RTR. There is an association of tubular injury beside the glomerular injury and the measurement of urinary enzymes as U.ALP could be a marker for assessment of the severity and progression of tubular injury and renal dysfunction in RTR.

Further prospective studies are required to assess targeting of CRT and CD47 as therapeutic strategies for CAD, renal fibrosis, limiting inflammatory reaction, and even prevention of renal deterioration.

The usefulness of serum CRT and CD47 as a potential simple biomarkers for detecting allograft dysfunction after renal transplantation needs to be validated in clinical trials with a large-scale population.

\section{Acknowledgements}

Not applicable.

\section{Authors' contributions}

HE formulated the hypothesis of the research, analyzed the results, and supervised the whole work. SA designed and performed the laboratory experiments and analyzed the data. SM collected the samples from the study participants and wrote the initial manuscript. RG revised the whole work and wrote the manuscript. All authors have read and approved the manuscript.

\section{Funding}

The research did not receive any specific grant.

\section{Availability of data and materials}

Not applicable.

\section{Ethics approval and consent to participate}

This study was approved by ethics committee of Faculty of Medicine, Alexandria University and the chairperson is professor Dr. Maha Ghanem and the IRB No.: 00012098 with approval no:: 0105124 . The participants provided written informed consent.

\section{Consent for publication}

The written informed consent was obtained from study participants.

\section{Competing interests}

The authors declare that they have no competing interests.

\section{Author details}

${ }^{1}$ Nephrology Unit, Faculty of Medicine, Alexandria University, Alexandria, Egypt. ${ }^{2}$ Department of Medical Biochemistry, Faculty of Medicine, Alexandria University, Alexandria, Egypt. ${ }^{3}$ Abu Keer Hospital, Ministry of Health, Alexandria, Egypt.

Received: 11 June 2020 Accepted: 4 September 2020

Published online: 03 November 2020

\section{References}

1. Rostand SG, Kirk KA, Rutsky EA, Pate BA (1982) Racial differences in the incidence of treatment for end-stage renal disease. N Engl J Med 306: 1276-1279
2. Cabello Benavente R, Quicios Dorado C, Lopez Martin L, Simon Rodriguez C, Charry Gonima P, Gonzalez Enguita C (2011) The candidate for renal transplantation work up: medical, urological and oncological evaluation. Arch Esp Urol 64:441-460

3. Morath C, Zeier M. Chronic allograft injury. In: Johnson RJ, Feehally, J, Floege J (eds.). Comprehensive Clinical Nephrology. 5th ed. Philadelphia: Elsevier: Saunders; 2015: 1214-1221.

4. Bos EM, Leuvenink HG, van Goor H, Ploeg RJ (2007) Kidney grafts from brain dead donors: Inferior quality or opportunity for improvement? Kidney Int 72:797-805

5. Ostwald TJ, MacLennan DH (1974) Isolation of a high affinity calciumbinding protein from sarcoplasmic reticulum. J Biol Chem 249:974-979

6. Fliegel L, Burns K, Opas M, Michalak M (1989) The high-affinity calcium binding protein of sarcoplasmic reticulum. Tissue distribution, and homology with calregulin. Biochim Biophys Acta 982:1-8

7. Williams DB (2006) Beyond lectins: the calnexin/calreticulin chaperone system of the endoplasmic reticulum. J Cell Sci 119:615-623

8. Inagi R (2009) Endoplasmic reticulum stress in the kidney as a novel mediator of kidney injury. Nephron Exp Nephrol 112:e1-e9

9. Docherty NG, O'Sullivan OE, Healy DA, Fitzpatrick JM, Watson RW. Evidence that inhibition of tubular cell apoptosis protects against renal damage and development of fibrosis following ureteric obstruction. Am J Phys Renal Phys 2006;290:F4-13.

10. Yamazaki T, Muramoto M, Nishimura S, Kita Y (2004) Suppressive effects of FR167653, an inhibitor of p38 mitogen-activated kinase, on calreticulin mRNA expression induced by endoplasmic reticulum stresses. Eur J Pharmacol 484:147-156

11. Chao MP, Jaiswal S, Weissman-Tsukamoto R, Alizadeh AA, Volkmer J, Gentles A J et al (2010) Calreticulin is the dominant pro-phagocytic signal on multiple human cancers and is counterbalanced by CD47. Sci Transl Med 2: 63 ra94

12. Obeid M, Tesniere A, Panaretakis T, Tufi R, Joza N, Van Endert P et al (2007) Ecto-calreticulin in immunogenic chemotherapy. Immunol Rev 220:22-34

13. Feng M, Chen JY, Weissman-Tsukamoto R, Volkmer JP, Yi Ho P, Mckenna KM et al (2015) Macrophages eat cancer cells using their own calreticulin as a guide: roles of TLR and Btk. Proc Natl Acad Sci U S A 112:2145-2150

14. Gold LI, Eggleton P, Sweetwyne MT, Van Duyn LB, Greives MR, Naylor SM et al (2010) Calreticulin: non-endoplasmic reticulum functions in physiology and disease. FASEB J 24:665-683

15. Oldenborg PA. CD47: A cell surface glycoprotein which regulates multiple functions of hematopoietic cells in health and disease. ISRN Hematol 2013; 2013: 614619.

16. Lindberg FP, Lublin DM, Telen MJ, Veile RA, Miller YE, Donis Keller $\mathrm{H}$ et al (1994) Rh-related antigen CD47 is the signal-transducer integrin-associated protein. J Biol Chem 269:1567-1570

17. Thakar CV, Zahedi K, Revelo MP, Wang Z, Burnham CE, Barone S et al (2005) Identification of thrombospondin 1 (TSP-1) as a novel mediator of cell injury in kidney ischemia. J Clin Invest 115:3451-3459

18. Ivanova NB, Dimos JT, Schaniel C, Hackney JA, Moore KA, Lemischka IR (2002) A stem cell molecular signature. Science 298:601-604

19. Rogers NM, Thomson AW, Isenberg JS (2012) Activation of parenchymal CD47 promotes renal ischemia-reperfusion injury. J Am Soc Nephrol 23: $1538-1550$

20. Vernon-Wilson EF, Kee WJ, Willis AC, Barclay AN, Simmons DL, Brown MH (2000) CD47 is a ligand for rat macrophage membrane signal regulatory protein SIRP (OX41) and human SIRPalpha 1. Eur J Immunol 30:2130-2137

21. Oldenborg PA, Gresham HD, Lindberg FP (2001) CD47-signal regulatory protein alpha (SIRPalpha) regulates Fcgamma and complement receptormediated phagocytosis. J Exp Med 193:855-862

22. Kahan BD, Dunn JK, Fills CM (1994) Neoral formulation: improued correlation between cyclosporine trough levels and exposure in stable renal transplant recipients. Transrlant Proc 26:2940-2946

23. Dacie JV, Lewis SM (1995) In: Practical hematology. 8th ed. Edinburgh: Churchill Livingstone 1:317-350

24. Whelton A, Waston AJ, Rock RG (2001) In: Tietz NW (ed) Fundamentals of clinical chemistry, 4th edn. WB Saunders, Philadelphia

25. Levey AS, Stevens LA, Schmid CH, Zhang YL, Castro AF, Harold I, Feldman $\mathrm{HI}$ et al (2009) A new equation to estimate glomerular filtration rate. Ann Intern Med 150:604-612

26. Hokama Y, Nakamura RM (1987) C-reactive protein: current status and future perspectives. J Clin Annal 1:15-27 
27. Moss DW (1982) Alkaline phosphatase isoenzymes. Clin Chem 28:2007-2016

28. Moss DW, Henderson AR, Kachmar JF (1987) In: Tietz NW (ed) Fundamentals of clinical chemistry, 3rd edn. WB Saunders, Philadelphia, pp 346-421

29. Jordan W (2009) Antigen measurement using ELISA. In: Walker JM (ed) The Protein protocols handbook, 3rd edn. Humana Press, New York, pp 1827-1833

30. Baxter GM (2001) Ultrasound of renal transplantation. Clin Radiol 56:802-818

31. Heptinstall RH (1992) Pathology of the kidney, 4th edn. Little Brown and Co, Boston, Toronto, London

32. Farris AB, Chan S, Climenhaga J, Adam B, Bellamy CO, Serón D et al (2014) Banff fibrosis study: multicenter visual assessment and computerized analysis of interstitial fibrosis in kidney biopsies. Am J Transplant 14:897-907

33. Prakoura N, Politis PK, Ihara Y, Michalak M, Charonis AS (2013) Epithelial calreticulin up-regulation promotes profibrotic responses and tubulointerstitial fibrosis development. Am J Pathol 183:1474-1487

34. Rizou M, Frangou EA, Marineli F, Prakoura N, Zoidakis J, Gakiopoulou H et al (2018) The family of 14-3-3 proteins and specifically 14-3-3r are upregulated during the development of renal pathologies. J Cell Mol Med 22: 4139-4149

35. Takemura Y, Ouchi N, Shibata R, Aprahamian T, Kirber MT, Summer RS et al (2007) Adiponectin modulates inflammatory reactions via calreticulin receptordependent clearance of early apoptotic bodies. J Clin Invest 117:375-386

36. Wang Y, Xie J, Liu Z, Fu H, Huo Q, Gu Y et al (2017) Association of calreticulin expression with disease activity and organ damage in systemic lupus erythematosus patients. Exp Ther Med 13:2577-2583

37. Hashaad NI, Fawsy RM, AboElazem AA, Youssef MI (2017) Serum calreticulin as noval biomarker of juvenile idiopathic arthritis disease activity. Eur J Rheumatol 4:19-23

38. Sun C, Zhou X, Zou Z, Guo H, Li J, Qiao C (2016) Clinical manifestation of calreticulin gene mutations in essential thrombocythemia without Janus Kinase 2 and MPL mutations: A chinese cohort clinical study. Chin Med J 129:1778-1782

39. Raghavan M, Wijeyesakere SJ, Peters LR, Del Cid N (2013) Calreticulin in the immune system: ins and outs. Trends Immunol 34:13-21

40. Feng $M$, Chen JY, Weissman-Tsukamoto R, Volkmer JP, Ho PY, McKenna KM et al (2015) Macrophages eat cancer cells using their own calreticulin as a guide: Roles of TLR and Btk. PNAS 112:2145-2150

41. Chao MP, Majeti R, Weissman IL (2012) Programmed cell removal: a new obstacle in the road to developing cancer. Nat Rev Cancer 12:58-67

42. Navarro-Alvarez N, Yang YG (2011) CD47: a new player in phagocytosis and xenograft rejection. Cell Mol Immunol 8:285-288

43. Grimbert $\mathrm{P}$, Bouguermouh S, Baba N, Nakajima T, Allakhverdi Z, Braun D et al (2006) Thrombospondin/CD47 interaction: a pathway to generate regulatory $\mathrm{T}$ cells from human $\mathrm{CD} 4^{+} \mathrm{CD} 25^{-} \mathrm{T}$ Cells in response to inflammation. J Immunol 177:3534-3541

44. Dou J, Liu P, Wang J, Zhang X (2006) Preliminary analysis of gene expression profiles in HepG2 cell line induced by different genotype core proteins of HCV. Cell Mol Immunol 3:227-233

45. Zhang W, Huang Q, Xiao W, Zhao Y, Pi J, Xu H et al (2020) Advances in antitumor treatments targeting the CD47/SIRPa axis. Front Immunol 11:18

46. Tena A, Kurtz J, Leonard DA, Dobrinsky JR, Terlouw SL, Mtango N et al (2014) Transgenic expression of human CD47 markedly increases engraftment in a murine model of pig-to-human hematopoietic cell transplantation. Am J Transplant 14:2713-2722

47. Latour S, Tanaka H, Demeure C, Mateo Y, Rubio M, Brown EJ et al (2001) Bidirectional negative regulation of human $T$ and dendritic cells by CD47 and its cognate receptor signal-regulator protein-a: Down-regulation of IL12 responsiveness and inhibition of dendritic cell activation. J Immunol 167: 2547-2554

48. Van Duyn Graham L, Sweetwyne MT, Pallero MA, Murphy-Ullrich JE (2010) Intracellular calreticulin regulates multiple steps in fibrillary collagen expression, trafficking, and processing into the extracellular matrix. J Biol Chem 285:7067-7078

49. Liu SH, Yang CC, Chan DC, Wu CT, Chen LP, Huang JW et al (2016) Chemical chaperon 4-phenylbutyrate protects against the endoplasmic reticulum stress-mediated renal fibrosis in vivo and in vitro. Oncotarget 7 : 22116-22127

50. Lee ES, Kim HM, Kang JS, Lee EY, Yadav D, Kwon MH (2016) Oleanolic acid and $\mathrm{N}$-acetylcysteine ameliorate diabetic nephropathy through reduction of oxidative stress and endoplasmic reticulum stress in a type 2 diabetic rat model. Nephrol Dial Transplant 31:391-400
51. Julovi SM, Sanganeria B, Minhas N, Ghimire K, Nankivell B, Rogers NM. Blocking thrombospondin-1 signaling via CD47 mitigates renal interstitial fibrosis. Lab Invest 2020; 4 May.

52. Malyszko Jl, Malyszko JS, Mysliwiec M (2009) Serum neutrophil gelatinase associated lipocalin correlates with kidney function in renal allograft recipients. Clin Transpl 23:681-686

53. Uslu B, Efe O, Alatas N, Kebapi O, Colak G (2005) Urinary enzymes as screening markers of renal dysfunction in diabetic patients. J Nephrol 18: 559-567

54. Swedenberg P, Hultberg B, Thysell H (1981) Urinary-hexosamini-dase excretion in polycystic kidney disease. Acta Med Scan 210:471-473

55. Gatua WK, Makumi JN, Njagi EM, Kigondu CS, Mcligeyo SO, Waithaka SK (2011) Evaluation of urinary tubular enzymes as screening markers of renal dysfunction in patients suffering from diabetes mellitus. Asian J Med Sci 3:84-90

56. Câmara NO, Silva MS, Nishida S, Pereira AB, Pacheco-Silva A (2004) Proximal tubular dysfunction is associated with chronic allograft nephropathy and decreased long-term renal-graft survival. Transplantation 78:269-275

\section{Publisher's Note}

Springer Nature remains neutral with regard to jurisdictional claims in published maps and institutional affiliations.

\section{Submit your manuscript to a SpringerOpen ${ }^{\circ}$ journal and benefit from:}

- Convenient online submission

- Rigorous peer review

- Open access: articles freely available online

High visibility within the field

- Retaining the copyright to your article

Submit your next manuscript at $>$ springeropen.com 